\title{
BOOK REVIEW \\ POLITICAL MAN : THE SOCIAL BASES OF POLITICS SEYMOUR MARTIN LIPSET NEW YORK: ANCHOR BOOKS, 1963
}

\author{
Purnama Julia Utami
}

\begin{abstract}
ABSTRAK
Buku ini secara keseluruhan membahas tentang Demokrasi, dan kondisi sosial yang mendukung demokrasi, baik yang bersumber pada budaya politik maupun struktur politik. Lipset menyadari bahwa pertumbuhan dan kondisi ekonomi negara yang menerapkan demokrasi merupakan kondisi sosial yang paling penting yang mendukung demokrasi. Lipset berargumentasi secara tegas bahwa semakin tinggi kemakmuran ekonomi sebuah negara maka semakin besar peluang mewujudkan demokrasi. Secara nyata Lipset dalam buku ini, memfokuskan audiens pada teritorial Eropa dan Amerika, karena kedua negara tersebut memiliki sejarah yang panjang sebagai negara dengan konflik status sosial yaitu perjuangan antar kelas agar dapat diakui keberadaannya oleh negara.
\end{abstract}

\section{PEMBAHASAN}

Buku ini membahas tentang faktor-faktor yang menguatkan atau melemahkan demokrasi dengan menggunakan teori Konflik kelas dan Konsensus (Karl Marx \& Alexis de Tocqueville), dan Birokrasi dan Demokrasi (Max Weber \& Robert Michels)

1. Kelas, Konflik dan Konsensus: Marx dan Tocquevile, Teori Marx tidak memberikan tempat bagi demokrasi di bawah komunisme. Hanya ada dua tipe sosial yaitu masyarakat konflik atau masyarakat harmoni. Tipe pertama adalah masyarakat yang secara alamiah merusak kemanusiaan dan harus dihancurkan. Tipe kedua adalah masyarakat yang bebas dari sumber konflik dan karenanya tidak membutuhkan institusi dan praktik yang demokratis. Teori Tocqueville sekilas serupa dengan teori Marx karena keduanya menekankan ikatan yang erat dari unit unit sosial dan perlunya konflik di antara unit-unit ini. Tocqueville secara sengaja memilih untuk menekankan aspek-aspek sosial ini yang bisa menjaga pemisahan politik dan konsensus politik pada saat yang bersamaan. Interpretasi Tockueville tentang kecenderungan dari masyarakat modern memunculkan sebuah perhatian serius tentang sistem politik pluralis, dimana sebuah sistem politik dengan banyak kelompok berbeda diperbolehkan secara sah untuk mempengaruhi kebijakan publik.

2. Birokrasi dan Demokrasi : Weber dan Michels, Studi tentang Birokrasi identik dengan Marx Weber dan Robert Michels. Mereka melakukan penelitian bahwa, problem politik modern bukanlah kapitalisme atau sosialisme tetapi hubungan antara birokrasi dan demokrasi. Keduanya mencoba menunjukan bahwa organisasi sosial dan masyarakat itu akan menjadi birokratis dan oligarkis seperti kapitalisme.

Teori Weber dan Michels tentang birokrasi dan demokrasi bersama dengan teori Marx dan Tocqueville tentang konflik dan konsensus menjadi perhatian utama dari sosiologi politik modern yaitu:

a. Pemungutan Suara (voting)

b. Gerakan Politik (political movement)

c. Politik Birokrasi (politics of bureaucacy)

d. Pemerintahan internal organisasi mandiri (internal government of voluntary organization)

e. Institusi yang mendorong unifikasi sosial (institution assisting social unification)

Menurut Lipset Demokrasi di dalam masyarakat maju bisa didefinisikan sebagai sistem politik yang memiliki pengaturan konstitusi tentang pergantian para pejabat pemerintah, bersama-sama dengan pengaturan sosial yang memperbolehkan sebagain besar penduduk, untuk turut mempengaruhi keputusan penting dengan cara oposisi untuk menduduki jabatan politik. Definisi ini secara umm diambil dari tulisan ekonom Austria-Amerika Joseph Schumpeter dan Max Weber, yang memiliki implikasi pada 3 kondisi khusus yaitu : 
1. Keyakinan yang berkaitan dengan institusi yang dianggap sah, yakni diterima oleh partai politik, pers;

2. Sekelompok pemimpin politik yang berkuasa;

3. Kelompok pemimpin yang diakui bersaing memperebutkan kekuasaan.

Untuk memperluas kondisi tersebut diatas, demokrasi akan menjadi kacau, sistem politik tidak memilik nilai yang mengatur tentang persaingan memperebutkan kekuasaan secara damai, kemudian hasil dari aktifitas politik tidak menuju pada pemberian kekuasaan yang efektif kepada satu kelompok, sehingga akan membuat pemerintahan tidak stabil dan kurang bertanggung jawab, dan pengaruh rakyat terhadap kebijakan akan berkurang.

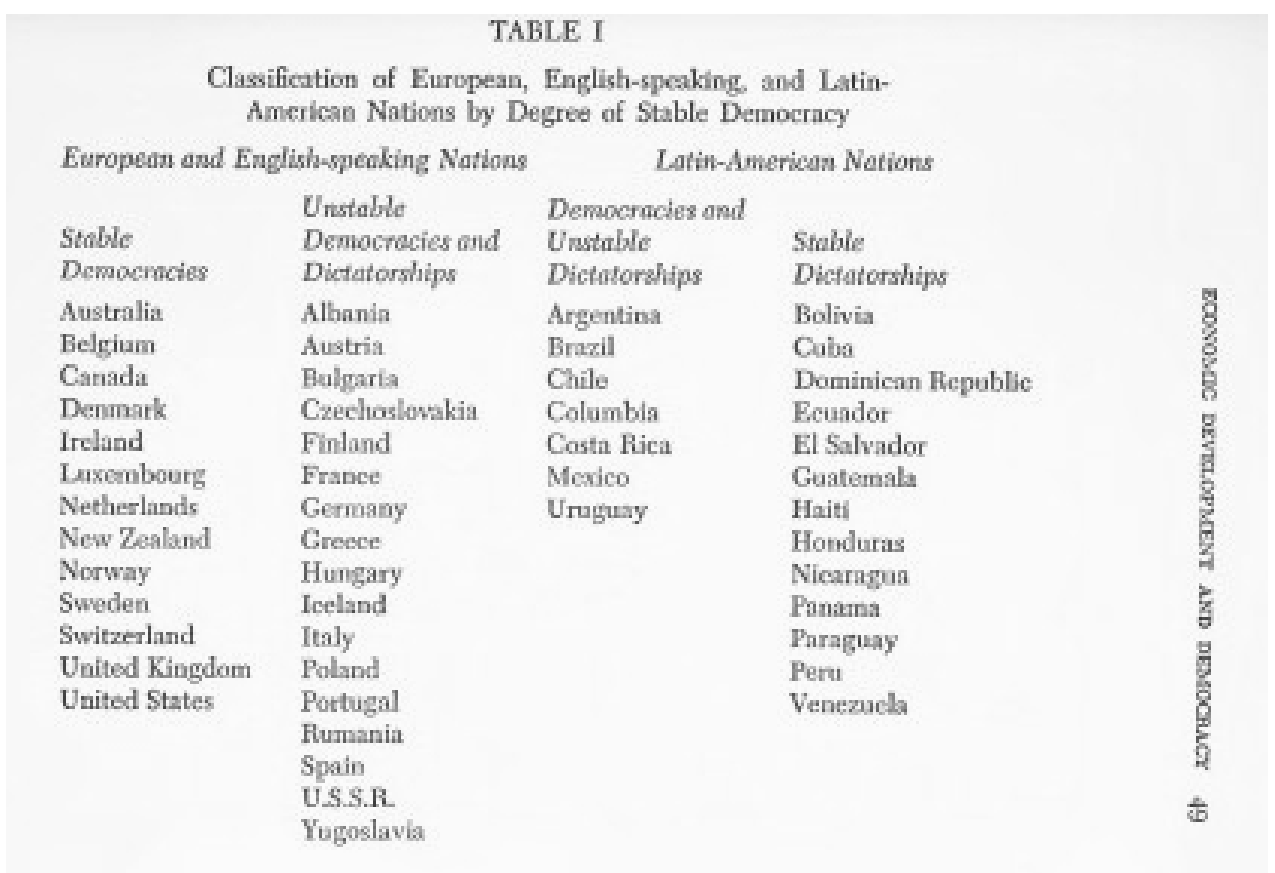

\section{Gambar 1. Klasifikasi Demokrasi Stabil dan Tidak Stabil. Seymour Martin Lipset. Political Man. p.49}

Standar utama yang digunakan untuk mendefinisikan demokrasi di negara Eropa adalah kelangsungan demokrasi politik yang terputus semenjak perang dunia pertama dan tidak adanya gerakan politik yang besar menentang proses demokrasi selama dua puluh lima tahun terakhir. Bagi Amerika latin standar yang digunakan adalah Beberapa negara telah memiliki sejarah pemilihan umum relatif bebas sejak perang dunia pertama.

1. Pertumbuhan ekonomi di Eropa dan Amerika, Untuk menguji asumsi ini Lipset menggunakan berbagai indeks dari pertumbuhan ekonomi: kemakmuran, industrialisasi, urbanisasi dan pendidikan. Setelah mengkonversi indeks tersebut ke dalam terminologi statistik, maka akan didapat negara-negara yang secara umum secara lebh atau kurang demokratis di Eropa dan Amerika.

Dengan memisahkan ukuran tersebut, akan didapatkan hasil yang memperlihatkan perbedaan, yaitu:

1. Kemakmuran: ukuran kemakmuran yang digunakan adalah:

a. Pendapatan perkapita;

b. Perbandingan banyaknya orang terhadap jumlah kendaraan;

c. Jumlah pasien dari seorang dokter;

2. Industrialisasi: ukuran yang digunakan adalah:

a. Persentasi penduduk pria yang bekerja di sektor pendidikan;

b. Pemakaian energi yang diproduksi secara komersial di negara tersebut.

3. Urbanisasi, Ukuran yang berbeda ditunjukan dari data yang dihimpun oleh institute of international urban research, Berkley, California, mencerminkan hubungan antara urbanisasi dan demokrasi:

a. Persentase penduduk pada komunitas sedikitnya 20.000;

b. Persentase penduduk pada komunitas antara 100.000 orang atau lebih; 
c. Persentase penduduk di kawasan metropolitan.

4. Pendidikan, Mengenai pendidikan, informasi perbandingan yang tersedia mendukung apa yang telah ditunjuk para peneliti sebelumnya, yaitu, semakin tinggi tingkat pendidikan sebuah negara, maka semakin besar peluang bagi demokrasi. Disamping persentase tingkat melek huruf, jumlah orang yang bersekolah dari tiap level pendidikan juga konsisten terhadap tingkat demokrasi.

Kontribusi pendidikan bagi demokrasi telah dibuktikan lebih jelas dan lebih kuat daripada tindakan individu.

2. Pembangunan Ekonomi Dan Perjuangan Kelas

Pembangunan ekonomi secara umum menentukan bentuk perjuangan kelas, karena memberi kesempatan pada kelompok masyarakat, dengan tingkat ekonomi rendah, untuk mengembangkan pandangannya. Bukti tentang in bisa didapati pada hubungan antara pola pendidikan kelas buruh, dengan pendapatan perkapita. Faktor kultural, historis dan politik mempengaruhi kehidupan politik bangsa-bangsa.

Pada dua negara paling kaya AS dan Canada, partai sosialis tidak pernah mampu menjadikan diri sebagai kekuatan yang besar. Partai sosialis memperjuangkan pemerataan produksi dan keuntungan di antara masyarakat, menawarkan program tengah antara kapitalisme dan komunisme.

\section{Politik Pertumbuhan Ekonomi Tinggi}

Problem politik dewasa ini disebabkan oleh tekanan dari industrialisasi yang cepat, gagasan ini menandai kemenangan determinisme ekonomi.doktrin yang menebtkan bahwa peristiwa ditentukan secara berangkai oleh ekonomi.

Tingkat pertumbuhan industri yang berbeda, peningkatan jumlah pekerja industri, dan konsentrasi indusri di kota diikuti oleh perbedaan dalam pertumbuhan kelompok atau partai politik. Kapitalisme menciptakan borjuasi yang kehadirannya menjadi pendorong bagi demokrasi.

\section{BAB III: Konflik Sosial, Legitimasi dan Demokrasi}

1. Legitimasi dan Efektifitas

Stabilitas demokrasi tergantung pada pertumbuhan ekonomi, efektifitas dan legitimasi sistem politik. Efektifitas diukur dai seberapa berhasil sistem memuaskan fungsi pemerintahan yang diukur dari reaksi sebagian besar penduduk negara tersebut, dan kekuatan seperti bisnis atau militer. Legitimasi mencakup kemampuan menghasilkan dan menjaga kepercayaan institusi politik adalah paling cocok bagi masyarakat.

Dalam rangka menganalisis stabilitas institusi politik dalam menghadapi krisis, penting untuk mengetahui tingkat relatif legitimasi institusi ini. Hubungan antara tingkat legitimasi dan efektifitas dari suatu sistem politik bisa dilihat dari bagan berikut ini:

\begin{tabular}{|l|c|c|c|}
\hline \multirow{3}{*}{ Legitimasi } & \multicolumn{3}{|c|}{ Efektifitas } \\
\cline { 2 - 4 } & & + & - \\
\cline { 2 - 4 } & + & $\mathrm{A}$ & $\mathrm{B}$ \\
\cline { 2 - 4 } & & $\mathrm{C}$ & $\mathrm{D}$ \\
\hline
\end{tabular}

Pengalaman politik dari negara berbeda pada awal 1930 an melukiskan efek dari kombinasi yang lain. Jerman dan Austria menetapkan sistem politik yag dianggap tidak sah oleh kekuatan besar pada akhir tahun 1920 1n, kendati demikian rezim tetap efektif, sehingga bisa dimasukan kedalam kotak C.

Efektifitas dalam dunia, berarti pertumbuhan ekonomi yang konstan. Negara dapat mengembankan sistem legitimasi yang baru dengan cara menyesuaikan diri.

2. Legitimasi dan Konflik

Ancaman laten terhadap sistem demokrasi adalah mengerasnya konflik bagi demokrasi, hingga pada titik yang bisa mengacaukan masyarakat.

Tiga isu besar yang muncul di negara Barat pada masa modern adalah:

a. Berbagai agama di dalam suatu negara; 
b. Penerimaan kelas rendah;

c. Pertarungan mengenai distribusi pendapata nasional.

Demokrasi yang stabil terkait dengan kondisi yang berbeda secara historis. Demokrasi tidak stabil dimana sejumlah pemisahan historis bercampur dan menciptakan basis bagi ideologi politik.

Semakin kuat dan berkaitan akar tradisi yang ada, amka semakin kurang potensi menuju toleran politik. Dalam sebuah demokrasi yang stabi ada ketegangan di antara kekuatan politik yang saling bersaing. Faktor yang melibatkan modernisasi dalam bentuk pembangunan ekonomi berasosiasi dengan mereka yang emiliki legitimasi dan toleransi yang mantap.

\section{Sistem-sistem Pemerintahan}

Aspek dari struktur Politik meliputi: (1). sistem dua partai lebih baik daripada sistem multi partai, (2). Pemilihan pejabat berdasarkan wilayah lebih cocok dengan representasi penduduk proporsional, (3). Federalisme Lebih Unggul dari negara kesatuan.

Jika kondisi sosial yang ada mendukung demokrasi, maka kombinasi banyak partai, representasi proporsional dan negara kesatuan tidak sepenuhnya melemahkan demokrasi. Faktor-fakor konstitusional yang mendorng banyak negara mengurangi kesempatan sistem demokrasi bisa bertahan.

4. Tantangan Kontemporer : Komunisme dan Nasionalisme

Negara-negara seperti Ghana, Guinia, Tunisia atau Meksiko, menyelenggarakan demokrasi yang lebih sebagai isyarakat penetapan demokrasi, dan sarana mengetahui pendapat publik untuk mendapatkan proses suksesi yang efektif. Dengan kelas menengah yang ada saat ini, perbedaan kecondongan politik kiri dan kanan tidaklah memadai sebagai sarana untuk membedakan pendukung dan lawan demokrasi.

Peluang terdapatnya demokrasi politik di Asia dan Afrika kurang baik, hal ini disebabkan oleh masyarakat miskin dalam jumlah yang besar, tingkat pendidikan rendah, struktur kelas yang tidak seimbang, dan kemenangan prematur demokrasi kiri.

\section{BAB IV: Otoriterisme Kelas Buruh}

Faktor-faktor tertentu bisa mengubah hubungan langsung antara otoriterime dan kelas sosial. Komitmen individu terhadap keyakinan atau organisasi politik yang berbeda juga merupakan kemenangan atas predisposisi yang paling mapan. Kecenderungan pada tingkat sosial yang khusus untuk mendukung partai ekstrimis atau demokrasi tidak bisa diprediksi berdasarkan pengetahuan atau sikap yang disimpulkan dari data survei. Baik bukti, maupun teori menunjukan bahwa:

a. Individu pada tingkat sosial lebih rendah relatif otoriter

b. Mereka akan lebih tertarik pada gerakan ekstrim ketimbang gerakan politik yang moderat dan demokratis, dan

c. Sekali mereka terikat dengan gerakan ekstrimis, mereka tidak akan tergoyahkan oleh demokrasi, yang memang kurang dikenal di lingkungan gerakan tersebut. yaitu:

Bab ini menjelaskan beberapa poin terkait otoritarianisme yang mencakup beberapa poin

1. Demokrasi dan Kelas Bawah, data statistik dari beberapa negara menunjukan bahwa kelas bawah kurang berkomitmen terhadap demokrasi, dibandingkan kelas menengah dan kelas atas di perkotaan.. Studi yang dilakukan pada tahun 1953 di Jerman, menghasilkan kesimpulan bahwa: Pada basis status okupasi, kelas buruh pada tingkat bawah dan pedesaan kurang memberikn dukungan terhadap sistem multipartai. Hasil serupa didapatkan pula pada hasil survei di Austria, Jepang, Brazil, Kanada, Meksiko, Jerman Barat, Belanda, Belgia, Italia dan Prancis pada tahun1958. Hal serupa juga ditemukan pada survey di Jepang, Inggris dan Amerika. Di Jepang misalnya buruh dan penduduk pedesaan ternyata lebih otoriter dan kurang peduli terhadap kebebasan sipil.

Bukti dari beberapa penelitian Amerika juga jelas dan konsisten bahwa, Kelas bawah merupakan kelompok yang kurang toleran. Kesimpulan ini didasarkan pada sampel nasional yang diambil pada hapir 5000 orng Amerika. 
2. Agama Ekstrim dan Kelas Bawah, Hubungan langsung antara basis sosial ekstemisme politik dan keagamaan telah diteliti di banyak negara. Di Rusia di masa kekuasaan Tsar. Leon Trotsky muda mengakui hubungan tersebut dan berhasil merekrut anggota parlemen pertama dari kelas buruh pada Serikat Buruh Rusia Selatan dari sekte keagamaan. Di Belanda dan Swedia, studi menunjukan bahwa komunis memiliki dukungan kuat $d$ wilayah yang sebelumnya dikenal sebagai pusat dari salah satu tipe gerakan fundamentalisme yaitu revivalisme. Inti dari poin ini adalah fundamentalisme yang kaku dan otoritarian religius berkaitan dengan karakteristik dasar, sikap dan keyakinan yang sama, yang mungkin juga muncul pada keterkaitan orang pada gerakan politik ektrimis.

3. Situasi Sosial Kelas Bawah, Menurut survei hasil pemilihan umum seperti Italia, Prancis dan India, para pemilik pertanian besar adalah kelompok yang sangat mendukung partai Fasis, sementara para buruh dan petani muskin, memberikan dukungan terhadap komunis mereka juga lebih antusias dalam memberikan terhadap komunisme dibandingkan para buruh di sektor non pertanian.

Faktor yang membentuk cara berfikir kelas rendah ini adalah ketiadaan keamanan dalam hal ekonomi dan psikologi. Dalam kasus ini dukungan terhadap kelompok ekstrim, seringkali menjadi solusi jangka pendek dari ketidakamanan. Penelitian yang telah dilakukan menunjukan bahwa pengangguran, condong tidak toleran terhadap minoritas dibandingkan mereka yang memiliki pekerjaan. Ketidakamanan kelas bawah dan ketegangan karena instabilitas ekonomi juga didukung oleh pola keluarga khusus, terdapat hubungan langsung antara frustasi dan agresi dalam kehidupan sehari-hari, dari mereka pada kelas bawah baik di kalangan anak-anak maupun orang dewasa.

4. Cara Pandang Kelas Bawah, banyak studi yang memusatkan perhatian pada beragam aspek kehidupan dan kultur kultur kelas buruh menekankan karakteristik mengenai cara pandang yang sempit. Sugesti yang menonjol, ketiadaan pertimbangan masa lampau dan masa depan, ketidakmampuan melakukan pandangan yang kompleks, kesulitan dalam menangkap gagasan atau prinsip, terlibat didalam pengalaman nyata dan ketiadaan imajinasi merupakan karakteristik yang disebut oleh peneliti sebagai karakterstik dari kelas bawah.

5. Terbentuknya Otoriterisme Amerika, akibat politik dari kecenderungan individu pihak bawah pada gerakan ekstrimis bisa menghasilkan penarikan dari aktivitas politik dan kepedulian pada kondisi yang berbeda.

6. Ekstremisme sebagai Sebuah Alternatif: Ujian Bagi Asumsi atau Hipotesis, Ekstrimis mewakili bentuk politik yang lebih kompleks, partai komunis adalah partai kecil yang sedang berjuang menhadapi partai reformis yang kuat seperti di Inggris, Amerika, Swedia, Norwegia. Ketika partai komunis keci dan lemah, maka partai ini tidak bisa memberikan janji untuk menghadirkan perubahan yang cepat. Sebaliknya partai komunis tersebut akan merepresentasikan argumentasi intelektual yang kompleks yang dikuatkan oleh kecenderungan dasar dari sistem ekonomi dan sosial.

7. Pola Historis dan Tindakan Demokratis, dalam sejarah hanya sedikit kelompok yang secara sukarela mendukung kebebasan dan kemerdekaan sipil untuk mereka yang mengadvokasi tindakan yang mereka anggap bahaya atau harus dihapuskan. Kebebasan beragama muncul di dunia barat karena kekuatan yang bersaing mendapati bahwa, mereka tidak bisa menghancurkan pihak yang lain tanpa menghancurkan masyarakat itu sendiri.

\section{BAB V: Fasisme: Kiri, kanan dan Tengah}

Sebelum tahun 1917 gerakan politik yang menentang demokrasi biasanya dianggap gerakan kanan, mereka yang handak menghapuskan demokrasi biasanya bertujuan memulihkan monarki atau pemerintahan aristokrasi. Pada waktu terjadinya revolusi komunis di Rusia para politisi dan intelektual mulai merujuk baik gerakan kiri maupun kanan, berkembang menjadi gerakan yang mengadvokasi kediktatoran. Sementara kekuatan moderat di tengah tetap menjadi pembela demokrasi.

1. Fasisme dan Kelas Menengah 
Gagasan bahwa fasisme adalah gerakan kelas menengah adalah sama sekali tidak berdasar. Dukungan terhadap ekstrimis mungkin juga bisa merupakan tanggapan terhadap dampak sosial industrialisasi.

2. Jerman

Nazi yang dipimpin oleh Adolf Hitler, adalah partai fasis revolusioner menurut kalangan Marxian, partai ini meakili tahapan akhir dari kapitalisme, dalam rangka melindungi institusi kapitalisme yang sedang merosot. Nazi mendapatkan dukungan sangat besar di kalangan partai liberal kelas menengah, bekas pendukung utama Republik Weimar.

Di Antara partai yang mengikuti pemilu pada tahun 1928, yang kehilangan pendukung sangat besar adalah Wirtschaftspartei, yang mewakili usahawan kecil dan pengrajin. Adapun partai yang dapat mempertahankan separuh proporsi pemilihnya adalah Partai Nasionalis Sayap Kanan lawan dari Weimar dan DNVP yang merupakan satu-satunya partai non Marxis dan Non Katolik. Kedua partai ini merupakan partai paling nasionalis dan paling konservatif pra-Nazi, sebagai penentang utama perjanjian Versaille. Sehingga kita dapat berargumen bahwa Nazi mengalahkan konservatif di wilayah-wilayah dimana Nasionalisme merupakan kekuatan terbesar dari partai konservatif tersebut.

3. Austria

Nazi mendapatkan dukungan dari pemilih di wilayah kelas menengah Austria Non Yahudi selama lebih dari setahun sebelum Nazi sendiri mengambil alih pemerintahan di Jerman dan menggantikan Partai Rakyat sebagai partai ketiga terbesar pada berbagai pemilu provinsi di Austria antara tahun 1931-1932.

Arena politik Austria juga memberikan gambaran tentang karakter khusus fasisme konservatif. Dan tahun 1934 partai konservatif Austria menerapkan pemerintahan diktator; tidak ada kekuatan politik yang mendapatkan tekanan kecuali yang mengorganisir ooposisi terhadap rezim. Tahun 1938 Nazi yang totaliter berusaha mengontrol masyarakat dengan menghancurkan kekuatan sosialis dan serikat buruh bawah tanah, tidak peduli mereka terlibat atau tidak di dalam politik.

4. Prancis

Temuan dari survei yang dilakukan di Prancis, menyatakan bahwa masyarakat Prancis lebih condong untuk tidak mempercayai lembaga parlemen dan menginginkan pemerintahan dengan pemimpinnyang kuat.

5. Italia

Fasisme Italia berawal dari partai Neo Sosialis, gerakan ini mengambil setiap kesempatan yang tersedia untuk mendapatkan dukungan dari beragam kelas sosial. Data yang ada menunjukan bahwa konsentrasi terbesar pemilih Neo Fasis adalah masyarakat kecil, yang memiliki basis massa di wilayah pedesaan miskin dan kota kecil yang tidak memiliki dampak urbanisasi. Perbedaan antara Neo Fasis Italia dan noe fasis di negara lain adalah gerakan fasisme italia dibangun setelah fasisme berkuasa.

6. Amerika Serikat: McChartysme sebagai populisme ekstrim

Gerakan populis kehilangan sebagian besar pengaruh politik mereka dengan pertumbuhan industri yang pesat. Pada tahun 1930, gerakan fasis mencoba mendapatkan kekuatan dengan mengkampanyekn kepentingan para petani dan pedagang kecil, menyerang lembaga demokrasi dan menyalahkan kesulitan ekonomi dan sosial kepada pengelola keuangan.

Kelima gerakan ekstimis nasional yng sudah disebutkan diatas, merupakan dukungan yang menarik kaum urban mandiri dan kelas menengah pedesaan, yang merupakan produk frustasi yang tidak adajalan keluarnya.

7. Peronisme: Fasisme Kelas Bawah

Peronisme adalah gerakan ekstrim, yang terbentuk seputar berkusanya Presiden Argentina Juan Peron pada tahun 1946-1955. Peronisme hampir seperti partai marxis yang diarahkan pada masyarakat miskin terutama buruh urban dan juga penduduk miskin di pedesaan. Peronisme merupakan kombinasi dari semua kebijakan yang mirip program partai buruh radikal dengan karakteristik, nasionalisme ekstim, penekanan 
tentang peran dominan pemimpin, ideologi ekonomi serupa fasisme Mussolini dan kurang memberikan penghargaan terhadap konstitusi dan tradisi.

8. Basis Sosial Fasisme

Basis Fasisme adalah kaum yang marah terhadap negara, orang dengan kegagalan personal, mereka yang terisolasi secara sosial, mereka yang ekonomi tidak aman, tak berpendidikan, tidak memahami komplexsitas sosial, dan orang dari beragam status yang memang otoriter. Gerakan ekstimis didukung oleh mereka yang gagal kencaai keberhasilan dalam bisnis atau pekerjaan dan mereka talah kehilangan status sosial.

\section{BAB VI: Pemilu: Siapa Memilih dan Siapa Tidak Memilih}

Pola partisipsi pemilih seperti di Jerman, Swedia, Amerika, Norwegia, dan Finlandia memperlihatkan kesamaan yang menyolok yaitu:

1. Persentasi pria yang memberikan persentasi lebih menyolok ketimbang wanita;

2. Pemilih berpendidikan tinggi memiliki persentasi lebh besar;

3. Pemilih dari penduduk perkotaan lebih tinggi dibanding penduduk pedesaan;

4. Mereka yang berumur 35-55 memiliki persentase yang tinggi untuk memberikan suara di pemilu dibandingkan dengan pemilih pemula

5. Orang yang telah menikah memiliki persentasi lebih besar dibandingkan yang tidak menikah

6. Orang yang menjadi anggota organisasi memiliki persentase memilih lebih tinggi.

Berikut ini adalah perbedaan deskriptif dalam pemberian suara yang telah ditempatkan dalam tabel di bawah ini:

\begin{tabular}{|c|c|}
\hline Tingkat Pemilih Tinggi & Tingkat Pemilih Rendah \\
\hline $\begin{array}{l}\text { Pendapatan Tinggi } \\
\text { Pendidikan Tinggi }\end{array}$ & $\begin{array}{l}\text { Pendapatan Rendah } \\
\text { Pendidikan Rendah }\end{array}$ \\
\hline $\begin{array}{l}\text { Kelompok Pekerjaan: } \\
\text { Usahawan } \\
\text { Pekerja Kerah Putih } \\
\text { Pegawai Negeri } \\
\text { Petani Komoditas Komersial } \\
\text { Buruh Tambang }\end{array}$ & $\begin{array}{l}\text { Kelompok Pekerjaan: } \\
\text { Buruh tanpa keahlian } \\
\text { Pembantu rumah tangga } \\
\text { Buruh Jasa } \\
\text { Petani yang bekerja untuk hidup }\end{array}$ \\
\hline $\begin{array}{l}\text { Kulit Putih } \\
\text { Laki-Laki }\end{array}$ & $\begin{array}{l}\text { Kulit Hitam } \\
\text { Perempuan }\end{array}$ \\
\hline $\begin{array}{l}\text { Orang di dalam usia } 35-55 \\
\text { Orang tua diatas } 55 \text { tahun }\end{array}$ & Orag dibawah 35 \\
\hline $\begin{array}{l}\text { Warga masyarakat yang telah lama } \\
\text { tinggal }\end{array}$ & Pendatang baru dalam masyarakat \\
\hline Buruh di Erpa Barat & Buruh di Amerika Serikat \\
\hline Situasi Krisis & Situasi Normal \\
\hline Orang yang menikah & Lajang \\
\hline Anggota organisasi & Individu yang hidup terisolasi \\
\hline
\end{tabular}

Klasifikasi lebih lanjut dari faktor ini ditemui dalam kelompok sosial yang kongkret yaitu:

I. Relevansi kebijakan pemerintah terhadap individu:

a. Tergantung kepada pemerintah sebagai pegawai

b. Terkena tekanan ekonomi yang membutuhkan tindakan pemerintah

c. Terkena pembatasan ekonomi oleh pemerintah

d. Memiliki nilai moral atau agama yang terpengaruh oleh kebijakan pemerintah

e. Tersedianya kebijakan alternatif

f. Situasi krisis yang umum

II. Akses terhadap informasi:
a. Melihat langsung dampak beijakan pemerintah
b. Pelatihan pekerjaan dan pengalaman untuk membuat pandangan umum
c. Kontak dan komunikasi
d. Tersedianya waktu di luar kerja

III. Tekanan Klompok Untuk memilih: 
a. Kurang diuntungkan dan teraleniasi

b. Kekuatan organisasi politik kelas

c. Jangkauan kontak sosial

d. Norma kelompok yang menentang pemberian suara

IV. Tekanan ssilang yang bertentangan:

a. Kepentingan yang bertentangan

b. Informasi yang bertentangan

c. Tekanan kelompok yang bertentangan.

\section{BAB VII: Pemilu: Perjuangan Kelas Secara Demokratis}

Dalam demokrasi modern konflik antara kelompok berbeda disalurkan melalui partai politik yang mempresentasikan perjuangan kelas secara demokratis. Sat generalisasi pokok yag berlaku secara internasional adalah partai politik pada prinsipnya berbasis pada dua kelompok kelas, yaitu kelas bawah dan kelompok kelas menengah-atas. Sebuah bukti terpercaya tentang kecondongan pilihan politik secara umum buruh dan petani. Karakteristik ini dibuat berdasarkan pendapat umum dan survei informasi hingga 1957 di berbaai negara yaitu AS, Argentina, Chili, Brazil, Kanada, Australia, Jepang, Finlandia, Norwegia, Swedia, Denmark, Jerman, Belanda, Belgia, Prancis, Austria, Italia, Inggris dan Hungaria.berkut tabelnya:

\begin{tabular}{|l|l|}
\hline \multicolumn{1}{|c|}{ Suara Pemilih Kiri lebih Tinggi } & \multicolumn{1}{|c|}{ Suara Pemilih Kiri Lebih Rendah } \\
\hline Kota besar & Kota kecil, pedesaan \\
Banyak pabrik besar & Pabrik skala kecil \\
Pengangguran Tinggi & Pengangguran rendah \\
Minoritas etnis atau agama & Mayoritas etnis dan agama \\
Laki-laki & Perempuan \\
Wilayah maju secara ekonomi & Wilayah terbelakang secara \\
Buruh & ekonomi \\
Posisi Pekerjaan: & Pekerja kantor \\
- Buruh tambang & Posisi Pekerjaan: \\
- Nelayan & $-\quad$ Pegawai negeri \\
- Petani komersial & - Pekerja sektor jasa \\
- Pelaut, buruh pelabuhan & - Petani \\
Pekerja dengan keterampilan & Buruh detangan kenggarap \\
rendah & \\
\hline
\end{tabular}

Meskipun tampaknya nyata bahwa faktor faktor struktural yang menentukan pilihan terhadap partai dalam sebuah masyarakat modern bisa dilihat dari tingkatan kelas, jelas disini juga terdapat variabel sosial lain di luar kelas dan politik.

\section{BAB VIII: Pemilu: Perjuangan Kelas Demokratis Kelanjutan dan Perubahan}

Penekanan pada kelas sosial sebagai penyebab utama pilihan partai dan pembagian partai tampaknya mengkonfirmasikan ketakutan dari konservatif abad 19 bahwa masyarakt miskin akan memilih sesuai kepentingan mereka sendiri, kalau diberikan hak untuk memilih. Karena keyakinan ini konservatif di negara Barat menentang terciptanya sistem politik dimana pemerintahan yang mewakili mayoritas bisa membuat legislasi sesuai kepentingan mereka.

Terdapat beragam alasan, mengapa tidak terdapat hubungan yang erat antara kelas dan pemberian suara dalam pemilu. Namun terdapat fakta yang tetap bahwa hampir semua negara demokrasi yang stabil terdapat dorongan yang hampir alamiah menuju kiri. Sistem demokrasi kepartaian berbasis dua partai politik telah belangsung lebih lama di Amerika serikat di bandingkan di negara lainnya di dunia ini.

\section{BAB IX: Kelas dan Partai dalam Politik Amerika}

Studi tentang pandangan politik dari eksekutif bisnis pada 1900, 1925 dan 1950 melaporkan bahwa hampir tiga per empat pemilih memilih partai republik. Bahkan pada tahun 
1925 sebuah periode yang normalnya tidak dianggap sebagai massa konflik polotik kelas hanya 15 persen eksekutif bisnis memilih demokrat. Data ini tentu saja terlalu rendah untuk mewakili mayoritas Republik di kalangan eksekutif bisnis.

Perbedaan antara basis sosial dari partai Demokrat dan Republik, telah berlangsung lebih dari satu setengah abad. Politisi konservatif berusaha menghilangkan setiap penekanan terhadap perbedaan yang nyata antara partai tersebut: fakta bahwa kedua partai memiliki basis, mewakili kelas pada kelompok etnis dan agama berbeda. Hal ini disebabkan karena setiap partai ingin mendapatkan suara dari pemilih.

\section{BAB X: Intelektual Amerika: Politik dan Status Mereka}

Beberapa intelektual mengatakan bahwa posisi mereka yang terisolasi dari masyarakat,merupakan konsekuensi logis dari karakter dasar pekerjaan kemunculan mereka sebagai penentang nilai-nilai dan gaya hidup masyarakat kapitalis yang sedang tumbuh pada masa itu.

Definisi umum intelektual, adalah mereka yang berada dalam posisi mengkritik masyarakat dan mengambil jarak darinya. Namun intelektual tetaplah intelektual yakni pencipta dan penyebar kultur, bahkan ketika mereka sepenuhnya menjual diri pada nilai-nilai anti humanistik.

Intelektual Amerika telah dituduh sebagai posisi yang paling condong pada komunisme. Bukti-bukti menunjukan bahwa orang dengan pendidikan lebih baik akan lebih baik mendukung semua bentuk liberalisme non ekonomi termasuk kebebasan sipil bagi minoritas politik yang tidak populer.

Menganalisis sumber-sumber bagi orientasi kekirian Intelektual Amerika Serikat merupakan masalah yang kompleks, sebagian jawabab dari masalah ini terletak pada kondisi umum yang dialami masyarakat intelektual dengan dukungan besar ke partai kiri. Keterbatasan pilihan ideologi bagi intelektual Amerika berarti ahwa kaum konservatif condong untuk mendefinisikan cita-cita ideologi mereka dalam terminologi dari doktrin yang tersedia.

Merupakan fakta yang mengejutkan bahwa gambaran intelektual Amerika yang diyakini oleh kalangan wara negara sangat berbeda dengan gambaran mereka sendiri. Masyarakat menempatkan mereka sangat tinggi ketika ditempatkan dalam kedudukan status relatif. Banyak intelektual Amerika membuat penilaian dengan berangkat dari dominasi kultur populer tingkat rendah di Amerika, Amerikanisasi hanyalah sebuah peningkatan dalam standar hidup massa dan meyempitnya jurang antar kelas.

\section{BAB XI: Politik di Dalam Serikat Buruh}

Meningkatnya birokratisasi di dalam serikat buruh membantu melindungi hak hak buruh dan menguatkan posisi kepemimpinan serikat. Birokrasi sebagai pola pengorganisasian yang secara efektif memenuhi beragam kebutuhan memiliki akar yang kuat dalam serikat buruh.

Salah satu sumber kekuatan administrasi yang secara eksklusif tersedia bagi birokrasi yang memerintah adalah kontrol terhadap sarana komunikasi formalndi dalam organisasi. Hak individu tentang kebebasan berbicara hanya memiliki peran kecil sebagai alat kontrol efektif terhadap kekuasaan administratif.

Keberhasilan sebuah oligarki mengontrol organisasi besar adalah bervariasi tergantung pada tingkat keterlibatan anggota dalam organisasi. Instabilitas demokrasi dalam serikat buruh terjadi karena beberapa potensi yang bisa diatasi dengan mekanisme lokal yang mengakomodasikan beberapa masalah sebagai berikut:

1. Kebutuhan fungsional untuk menempatkan pemimpin dalam status tinggi;

2. Nilai dominandari bentuk mobilitas ke atas yang menjadi tujuan kultural;

3. Berlangsungnya sirkulasi atau rotasi kepemimpinan yang aman;

4. Dalam gerakan serikat buruh pemimpin yang dikalahkan berubah ke status yang lebih rendah jika mereka tetap berada dalam serikat buruh;

5. Penetapan demokrasi terhadap para pemimpin, akan menjadi peralihan besar dari pencapaian nilai dominan;

6. Penentuan standar yang bertentangan akan mengakibatkan hilangnya aturan bagi pemimpin dan merupakan situasi yang tidak memungkinkan. 
Walaupun demikian serikat buruh bisa turut mendukung demokrasi politik dalam lembaga politik yang lebih besar.

\section{KESIMPULAN}

Uraian yang digunakan dalam buku ini cukup jelas, Pengaturan sosial akan selalu berdampak pada keputusan politik yang dilaksanakan oleh pemimpin. Variabel yang digunakan dalam buku ini pembangunan ekonomi, kelas sosial, perjuangan kelas konflik sosial dan legitimasi. Adapun $n$ yang digunakan adalah negara Eropa dan Negara Berbahasa Inggris 30 kota, Amerika Latin 20 Kota, dan beberapa neraa Arab dan Asia turut serta dijadikan pembanding. Logika yang digunakan dalam buku ini adalah Pertama Similiar cases to finding the cause: Social conditions making democracy, which involves comparison of cases: Pembangunan ekonomi, konflik sosial dan legitimasi yang mengintegrasi masyarakat atau organisasi. Kedua Compares as contrasting cases as possible in order to show relationships between dependen dan independen variabel.

Pendekatan yang digunakan adalah multi variate analysis, sebagai jalan untuk mengkonseptualisasikan karakteristik yang kompleks dari sistem sosial. Terdapat hubungan kausalitas antara variabel yang dianalisis di dalam buku ini.

Buku ini menggunakan Variabel Oriented yang bertujuan melakukan generalisasi terhadap fenomena yang ada yaitu Kondisi pengaturan sosial akan menyebabkan negara memilih menganut sistem demokrasi atau non demokrasi yang secara langsung akan berpengaruh kepada birokrasi di dalam negara sample tersebut. 